\title{
LOOKING FOR GLOBAL TALENT IN ALL THE RIGHT PLACES: A CRITICAL LITERATURE REVIEW OF NON-TRADITIONAL EXPATRIATES
}

\author{
YVONNE MCNULTY \\ SIM UNIVERSITY, SINGAPORE \\ KATE HUTCHINGS \\ GRIFFITH UNIVERSITY, AUSTRALIA
}

\section{Introduction}

Much of the research on expatriation and global talent management has thus far focused on, and been predominantly driven by, a narrow definition of traditional international assignees (Adler, 2002; Haslberger \& Vaiman, 2013; Makela \& Suutari, 2009; Taylor, Napier, \& Mayrhofer, 2002), whom have typically been senior managers, Western, males in their late 40 s or early $50 \mathrm{~s}$, with an accompanying female spouse and children. Over the past decade the limited profile of the traditional expatriate has changed (Collings, Scullion, \& Morley, 2007; McNulty, 2014), largely because society, particularly in the Western world, has come to reflect considerable deviation from the traditional household composition of the past: fewer nuclear families; smaller numbers of household members; and more couples living together out of wedlock often with children (Duxbury, Lyons, \& Higgins, 2007; Office for National Statistics, 2012). Moreover across the developing world 'family' is often understood as encompassing extended family and broader community who often live in the same accommodation and share responsibilities for raising children - and yet their situations and implications for expatriating have received scant attention within the literature. Despite some organizations moving to localize their subsidiaries there is still considerable use of expatriates and movement of staff across international operations. Undoubtedly, the global talent pool is growing year-on-year with the latest estimates showing more than 8.5 million corporate expatriates existing worldwide (Brookfield Global Relocation Services, 2014). The talent pool is also increasingly staffed with less typical traditional expatriates (technical experts as opposed to senior managers, younger assignees in their mid-30's) and with more nontraditional expatriates than ever before - among them executive women, married couples without children, female breadwinners, single and unaccompanied men and women, younger early-career people, empty-nesters and semi-retired people over 60, split families, and samesex partnerships (Carlton \& Perelstein, 2013; Goby, Ahmed, Annavarjula, Ibrahim, \& Osman-Gani, 2002; McPhail, McNulty, \& Hutchings, 2016). This is in large part a direct response to society in general being more accepting of changing family situations, and to a lesser extent multinational enterprises (MNEs) demanding top talent in a tight labour market (Beechler \& Woodward, 2009; Findlay, 2006) which necessitates recruiting from a more diverse pool than has previously occurred. Yet, the experiences of women and men from both the developed and developing world within this non-traditional expatriate population are not well known. Beyond some recent studies of lesbian, gay, bisexual and transgender (LGBT) expatriates (Gedro, 2010; McPhail et al., 2016), and single-parent and split families (McNulty, 2015a), less is known about the challenges that global mobility managers face in compensating and supporting non-traditional expatriates from a policy perspective (Malecki, Day, Franklin, \& D’Argenio, 2013). Similarly, little is known about the experiences of nontraditional expatriates from their own perspectives. 
Our goal in this introduction and critical review of the literature, and in the Special Issue more broadly, is to explore the experiences of non-traditional expatriates and in so doing contribute to balancing the picture that existing research provides of the profile of expatriates. Specifically, we aim to: (i) define and examine types of non-traditional expatriates, (ii) address the gap in research that has not sufficiently addressed the experiences of this segment of the global talent pool; and (iii) propose a future research agenda to guide more scholarly work in this area. The Special Issue sits within the broader debate about diversity and inclusion within organizations (Baert, 2014; Fullerton, 2013; Hofhuisa, van der Zeeb, \& Otten, 2015; Mamman, 1995; Priola, Lasio, De Simone, \& Serri, 2014), and specifically international diversity in expatriation (Hutchings, Lirio, \& Metcalfe, 2012; McDonnell, Lamare, Gunnigle, \& Lavelle, 2010; Shortland, 2009; Stahl et al., 2012) - not just in terms of gender diversity, but also disability, sexual orientation, and age (Collins, 2009). Papers selected for publication in the Special Issue consider each of the outlined aims and provide innovative and leading edge insights into the opportunities and challenges faced by non-traditional expatriates. We must, however, provide a note of caution: research on nontraditional expatriates is a relatively new field of enquiry and continues to evolve, thus this critical introductory overview in addition to the papers presented here, while addressing new ground, also raise more questions than it answers. The overall value of the Special Issue, then, is to stimulate a future research agenda that considers expatriates whom sit outside of the context of traditional expatriates that have been conceptualized and studied to date.

Before introducing the papers in the Special Issue, we provide a critical literature review of non-traditional expatriates drawing on a broad literature base to provide the context for the papers that follow. We begin by exploring how non-traditional expatriates are defined with a particular focus on their family situation. We then discuss their varying types while considering the challenges that non-traditional expatriates face when engaging in expatriation.

\section{Defining non-traditional expatriates}

Non-traditional expatriates engaged in corporate global mobility (business expatriation) are defined by McNulty (2015a) as those that have 'special' circumstances that standard global mobility policies typically do not address. They differ from traditional expatriates in terms of their family composition (step, single-parent, split, overseas adoption, multi-generational) and family challenges (special needs or gifted children). They also differ in relation to family status (single expatriates, accompanying family members besides children), sexual orientation (lesbian, gay, bisexual, transgender), and gender (female breadwinners with male trailing spouses, single female expatriates). By defining non-traditional expatriates in this way we do not presume that they are excluded from the overall taxonomy of 'expatriates' but that they remain part of it on the basis that they live abroad and that one person in the family unit is engaged in legal paid work (Andresen, Bergdolt, Margenfeld \& Dickmann, 2014), being different only in relation to their individual or family characteristics and that they have erstwhile received scant attention in the literature or in organizational policy.

We define non-traditional expatriates in two ways. First, while new and different types of assignments have recently emerged as a way to replace long-term assignments of the past with more cost-effective solutions, e.g., commuter, rotational, short-term (Meyskens, von Glinow, Werther, \& Clarke, 2009), we distinguish non-traditional expatriates from nontraditional expatriation on the basis that our focus in this Special Issue is on the individual and the non-traditional nature of their family situation, not their assignment type (e.g., selfinitiated expatriation, short-term assignments, fly-in/fly-out project work). The distinction is important given the large number of paper submissions received for the Special Issue that implied self-initiated expatriates or people undertaking other than long-term corporate 
assignments are a type of non-traditional expatriate even though their samples actually reflected traditional family arrangements of heterosexual expatriate + spouse/partner (and often also + children). As outlined in the Call for Papers, we see the defining characteristics of non-traditional expatriates (rather than expatriation) as relating to their family situation. In other words, our focus is on the living arrangements of expatriates and specifically those that differ from research on traditional expatriates, and not the process of expatriation or assignment type per se. While it may well be that non-traditional expatriates are also engaged in non-traditional assignments, our focus is on the expatriates themselves and how their family status may affect their expatriate experience.

Second, we use the term 'non-traditional expatriate' as one that implies a family situation that is more encompassing than the restricted definition of a nuclear family consisting of a male breadwinner, female non-employed supporting spouse, and children of both parents (Rothausen, 1999). Our definition of non-traditional expatriates and their families also represents compositions such as female breadwinners, overseas adopted and step-children, and extended family members, among other variations. Thus, families constitute a range of different forms built from strong relationships. We borrow from McNulty (2014) in defining an expatriate family as,

married, de-facto, live-in, or long-term partners of the opposite or same-sex, with or without children, with family members that reside in one or many locations; and legally separated or divorced (single) adults with children, with family members that reside in one or many locations'

The definition of non-traditional expatriates we use accounts for a range of family situations and living abroad arrangements including: (i) cohabitation outside of legal marriage; (ii) children born outside of wedlock; (iii) blended families with step-children from prior relationships; (iv) children at boarding school geographically separated from their parents; (v) lesbian, gay, bisexual or transgender (LGBT) partnerships; (vi) overseas adoptions that take place during an assignment; (vii) split families residing in two or more locations; (viii) single parents with international custody arrangements; and, (ix) accompanying extended family. While our broader definition of expatriate families has not generally been considered in extant academic research, it is however been supported by practitioner literature. ORC Worldwide (2008) reported that the most prevalent definition of 'spouse' used by many MNCs $(38 \%)$ to define 'family' included a married, long-term or live-in partner of the opposite or same sex. KMPG (2011) similarly found that over half of the participants in their survey of $554 \mathrm{MNCs}$ include opposite-gender unmarried partners and nearly half include same-gender unmarried partners for the purposes of determining international assignment-related benefits. Both surveys found that the policy definition of 'dependents' includes biological, adopted and stepchildren.

\section{Types of non-traditional expatriates}

Non-traditional expatriates represent a diverse and growing segment of the global talent pool constituting up to eight different types of assignees (of a potentially larger pool) which we discuss herein. We acknowledge that our list is not exhaustive, noting that age issues in particular could extend our typology to also include semi-retirees and empty nesters (i.e., married couples without offspring or without offspring of dependent ages), among others. Moreover, we accept that some of the challenges that may be experienced by the types of non-traditional expatriates we identify may also be experienced when people relocate domestically (i.e., move within their own country of origin/residence) but we would 
nonetheless expect that obstacles may be greater for some groups (e.g., female expatriates, LGBT expatriates, expatriate adoption families) where there are cultural, social or legal constraints on activities in some international locations. One of the biggest challenges nontraditional expatriates face is self-discrimination, i.e., making a distinction against a particular decision based on the group, class, or category to which he or she belongs rather than on individual merit (Arrow, 1973). In the case of international career opportunities, nontraditional expatriates may self-discriminate by imposing irrelevant personal characteristics on the decision to expatriate (e.g., perceived barriers to mobility arising from their unique family situation) rather than properly relevant criteria (e.g., job skills, cultural intelligence, seniority, tenure). This can then result in self-imposed (and possibly also organizational) exclusion from working abroad as a result of turning down international assignments and not volunteering for opportunities when they arise or are presented. For some, it can lead to pursuing safer and often less-rewarding careers at home (Gedro, 2010; Gedro, Mizzi, Rocco, \& van Loo, 2013; McNulty, 2014) due to a perceived 'expatriate glass ceiling' or 'glass border'. Navigating stigmatization, marginalization and (self) discrimination can thus be challenging for some non-traditional employees whose motives for rejecting an international career opportunity may not be understood by those around them (Mamman, 1995; McNulty, 2015a). When they do expatriate, a key issue is the extent to which relocation policies can adequately address their practical needs, e.g., additional compensation (for airfares) to enable a single parent to facilitate his or her children's access to their other parent (Cartus, 2012b), or health insurance for a same-sex partner (UNDP, 2014).

As in other studies of traditional expatriates (Dickmann, Doherty, Mills, \& Brewster, 2008; Hippler, 2009), non-traditional expatriates have similar motives for undertaking international assignments, including career progression and financial stability as major drivers (McNulty, 2015a; McPhail et al., 2016; Tharenou, 2008). Enriching the cultural and general life experiences of their children (or other family members) and the family as a whole, is also important (Richardson, 2006). Further, while a number of theories have been applied to the acculturation of non-traditional expatriates, e.g., family systems theory, social capital theory, and ethical theory, among others (McNulty, 2014; McPhail et al., 2016; Tharenou, 2009), research on this emerging field of study remains in its infancy. Especially needed are in-depth studies that examine specific types of non-traditional expatriates so as to better understand how to support them at the organizational policy level. This includes studies that account for the 'double jeopardy effect' (King, 1988), i.e., when multiple non-traditional expatriate identities collide in two or more forms. For example, a female expatriate may suffer discrimination or stigmatization on the grounds of her femaleness as well as her ethnicity or class. For some expatriates, the intersection of multiple identities can be a disadvantage and a further barrier to mobility, whereas for others it presents no real challenge. From a talent candidate perspective, this is worthy of further study. Further, we need to be careful to avoid considering some family groups as homogenous or having the same needs. For instance, while research has examined challenges and opportunities for LGBT expatriates overall, the discrimination or stereotyping suffered by lesbians or gays or bisexuals or transgender people may differ according to individual identity and cultural context. Moreover, for some expatriates their family situation may reflect more than one situation which is not well recognized or supported by organizations, e.g., a lesbian expatriate may also have accompanying elderly parents, a gay expatriate may be the carer for a sibling with a disability, a single parent expatriate may also have a special needs child, and an overseas adoption family may also be a blended family (see example cases in McNulty, 2015a). We now turn to a critical literature review of different types of non-traditional expatriates and families. 


\section{Female expatriates}

Female expatriates are a growing phenomenon (Hutchings et al., 2012; Linehan, 2002; Tung, 2004) and the most frequently studied type of non-traditional expatriate (Caligiuri, Joshi, \& Lazarova, 1999; Caligiuri \& Tung, 1999; Cole \& McNulty, 2011; Fischlmayr \& Kollinger, 2010; Harvey \& Wiese, 1998; Haslberger, 2010; Punnett, Crocker, \& Stevens, 1992; Selmer \& Leung, 2002; Selmer \& Leung, 2003a, 2003b; Westwood \& Leung, 1994). Female expatriates are defined as women who are employed (generally) by MNEs being either single or married, and with or without children and may have been organizationally-assigned or selfinitiated their expatriation. The most commonly studied female expatriates, representing approximately $10 \%$ of the female expatriate population (Brookfield Global Relocation Services, 2014), are those in status-reversal marriages where the primary income is generated by the women (Drago, Black, \& Wooden, 2005). This implies that an accompanying partner is male (Cole, 2012; Punnett et al., 1992; Selmer \& Leung, 2003c).

The percentage of women sent on international assignments has increased over the last two decades, from three percent in the early 1990s (GMAC, NFTC, \& SHRM Global Forum, 2004) to 19 percent in 2015 (Brookfield Global Relocation Services, 2015). But while gender diversity has been shown as a corporate performance driver (Boatman, Wellins, \& Neal, 2011; Süssmuth-Dyckerhoff, Wang, \& Chen, 2012), particularly during expatriation (Adler, 1979; Cole \& McNulty, 2011; Guthrie, Ash, \& Stevens, 2003), female expatriates remain an under-utilized resource in international staffing (McKeen \& Bu, 2005; Selmer \& Leung, 2003a). Despite recent studies that show female expatriates often outperform their male colleagues (Cole \& McNulty, 2011), extant literature continues to suggest a number of reasons why women remain under-represented amongst expatriates relative to their male counterparts.

Research (e.g., Janssens, Cappellen, \& Zanoni, 2006) suggests that women can achieve greater career success through the strategic development of empowered identity. This implies that when women in the workforce feel emancipated from gender discrimination they foster higher levels of self and group esteem and move away from an oppressed group identity (Wilson, 1996). Yet, gender bias and stereotyping still prevail in the selection of female employees for international assignments (Fischlmayr, 2002; Paik \& Vance, 2002). Hutchings et al. (2008) found that female expatriates receive less organizational support than males. Moreover, specific countries are less appealing to females (or their employers) due to perceived differences in cultural distance from the home-country, political risk, and women not being accepted or suffering stereotyping in host-country contexts (Lowe, Downes, \& Kroeck, 1999; Selmer \& Leung, 2007). Moreover while women may have an interest in expatriating, commitments to family and challenges in managing work/life balance may prevent them from applying for or accepting international career opportunities (see Tharenou, 2008).

Given the potential number of female expatriates that might undertake international roles there is need for organizations to give greater consideration to issues around selection and support. As under-representation of female expatriates reflects under-representation of women in domestic positions and particularly amongst senior employees, more domestic mentors are necessary to provide women with role models who have successfully balanced work/life demands, have been promoted, and perhaps undertaken international positions. Organizations also need to consider how they support female expatriates in respect to providing financial and practical assistance with the caring responsibilities they have for children and other family members. Indeed, early research on female expatriates suggested that some women found an international assignment actually easier than working in their home country because of the affordability of outside home care and the availability of 
inexpensive domestic help in many expatriate locations (Adler, 1987). This finding points to a need for more consideration to be given to why women (and perhaps also their organizations) still believe that international work is too difficult to balance with family commitments. Additionally, there has been limited engagement with theory in the research which has examined female expatriates and most particularly it has been noted there is a need for reference to gender studies, social constructivism or post-modernist feminism (Hutchings \& Michailova, 2016).

\section{Split family expatriates}

Brookfield (2014) defines split family expatriates as those where an assignee is married (and may also have children) but is on assignment without a spouse/partner and the assignment is for one-year or longer. In other words, a split family is one where an international assignee's immediate family remains in the home country or a prior location while the assignee relocates 'unaccompanied' to the (new) host-location (ECA International, 2012; KPMG, 2011). These arrangements may be temporary, for example, to allow a child to finish the school year in the home/prior location before the family then re-joins the assignee in the new location; or permanent, for example, where an assignee enters into a 'commuter marriage' situation indefinitely due to a spouse's career or other family considerations (Hendershott, 1995; Merignac \& Roger, 2006; Worldwide ERC, 2011). Split families exist in three forms (Sullivan, Aldred, \& Taylor, 2013): (1) where a family stays in the home location and the assignee relocates with frequent trips home; (2) where the family and assignee relocate to a host country, but the family lives in a "tier 1 " city while the assignee commutes to a $2^{\text {nd }}$ or $3^{\text {rd }}$ tier city (in the same country) and returns on the weekends (this arrangement is common in non-governmental organizations such as the United Nations when families are sent to hardship or dangerous locations); and, (3) the family and assignee relocate to a 'livable' host country and the assignee commutes from there to a different country altogether. While (1) may be less expensive or cost neutral, and (2) and (3) more expensive, all are used across a number of industries and locations where the expense is viewed as a non-optional business cost of positioning key talent and candidates of choice (Brookfield Global Relocation Services, 2014). Split families are not typically defined by the absence of children who remain in their home country to attend boarding school, despite that nearly $30 \%$ of companies in a recent survey indicated that they provide additional home trips for parents to visit their children and $12 \%$ pay boarding school fees (Mercer, 2014a).

Sullivan et al. (2013) attribute the use of split family expatriates to several factors including the spouse/partner's unwillingness to let go of the family's two-income status, along with the perceived hardship that often comes with assignments to emerging markets. Richardson (2006) suggests that maintaining close relationships with extended family (e.g. grandparents, cousins) can also be important when deciding whether to expatriate (see Baldridge, Eddleston, \& Veiga, 2006). These reasons may explain why split family assignments are on the rise, with year-on-year increases of $10 \%$ annually (Brookfield Global Relocation Services, 2015). While nearly half of companies surveyed engage in split family assignments (Brookfield Global Relocation Services, 2014; KPMG, 2011), approximately $20 \%$ of an MNE's expatriate cohort elects to undertake an unaccompanied assignment (Cartus, 2012b) - a figure that has remained steady for the past six years since 2009.

While split family expatriates are used by MNEs to reduce the barriers to mobility and address talent shortages (Green, Hogarth, \& Shackelton, 1999), there are nonetheless likely to be significant personal costs arising from the separation and absence of a spouse from their partner and dependent children (Clegg, 2013b). This can include marital stress arising from the temporary single parent status of the at-home parent (Copeland, 2009; McNulty, 2015a). 
For the unaccompanied expatriate, it can lead to problems in the socialization process in the host-country in terms of distant social relationships and incomplete social networks among host-country nationals (HCNs) and within the expatriate community. Thus, without an accompanying spouse and children to act as socio-cultural brokers (Lauring \& Selmer, 2010; Merignac \& Roger, 2005), unaccompanied expatriates are less likely to establish meaningful social ties outside the organization in non-work settings that can potentially facilitate their adjustment (Johnson, Kristof-Brown, Van Vianen, De Pater, \& Klein, 2003; Merignac \& Grillat, 2012).

While organizations may provide financial support in the form of paying for schooling in the home country of an expatriate's children and regular flights home to facilitate relocation, we need to ask if there is more that organizations can do to support split family expatriates, e.g., providing a cultural induction to the family in the home country so they can better understand the challenges which the expatriate may face, and host country holidays for the expatriate's family.

\section{LGBT expatriates}

Lesbian, gay, bisexual and transgender (LGBT) expatriates are defined as a group of employees belonging to 'a sexual minority ... of people that cross international borders for professional reasons' (Gedro et al., 2013: p. 282). Although research on LGBT expatriates is growing (Gedro, 2010; Kaplan, 2014; McDevitt-Pugh, 2011; McPhail \& McNulty, 2015; Mercer, 2014b), most of these studies have not sufficiently explored the experiences of bisexual or transgender expatriates. Rather, the 'LGBT' label has been used as an overarching term to describe research that has primarily focused only on lesbian and gay expatriates (e.g., McNulty, 2015a; McPhail et al., 2016). Interest in LGBT expatriation is undoubtedly linked to increasing global awareness of 'gay rights', particularly in relation to marriage equality (The Straits Times, 2015b; Ungar, 2000) and anti-discrimination legislation that now includes sexual orientation and gender identity (Everly \& Schwartz, 2014; Ozturk \& Rumens, 2014). In the United States, along with other countries such as New Zealand, Argentina, The Netherlands and Uruguay, the State Department now gives equal treatment to the applications of LGBT married couples who wish to travel with their partner in much the same way that it does for heterosexual couples (Bohlen, 2012; Wroughton \& Heavey, 2013). Recent surveys show that $53 \%$ of Fortune 500 companies in the US provide same-sex partner benefits, with $98 \%$ of companies including sexual orientation in their non-discrimination policies (Brooks \& Edwards, 2009). As noted earlier, ORC Worldwide (2008) reported that the most prevalent definition of 'expatriate spouse' used by MNCs to determine international assignment-related benefits includes a married, long-term or live-in partner of the opposite or same-sex, suggesting that organizations and individuals are defining partnerships more broadly than they have in the past. KPMG (2011) found that nearly half of the participants in their survey of 554 MNCs include same-sex married or unmarried partners for similar purposes.

Despite the obvious suggestion that organizational support can greatly assist LGBT expatriates when they relocate abroad, complex mobility issues nonetheless exist for LGBT employees and the organizations that employ them (Collins \& Callahan, 2012; Kaplan, 2014; Leonard, 2004; Rocco, Landorf, \& Delgado, 2009). Homosexuality is punishable by death in seven countries and still illegal in a further 85 (McPhail \& McNulty, 2015; Silver, 2014) resulting in some countries being a 'no go' for LGBT employees. Studies show that LGBT expatriates often face a lack of support in the host country requiring them to deal (alone) with prejudice, discrimination and stigmatization, security and safety concerns, and insufficient access to family entitlements such as healthcare and pensions (Gedro et al., 2013; McNulty, 2014; McPhail et al., 2016). There may be further challenges relating to practical restrictions 
in terms of immigration and marital status for dependent spouses, a lack of entitlements necessary to raise children in relative normality, and being required to 'come out' to an employer in order to expatriate. In her study of female breadwinner expatriates, McNulty (2014) found that while these concerns are not unlike those experienced by non-expatriating (lesbian) employees, in the expatriate context there may be broader ramifications, e.g., fear of discrimination and stereotyping leading to limited career progression, lack of job security, and constant scanning for signs of acceptance (Brooks \& Edwards, 2009; Colgan \& McKearney, 2012; McFadden, 2015). McNulty (2014) also found that most LGBT expatriates do not have access to, and easy interaction with, other people like them resulting in multiple forms of duplicity (in/out) being used to hide their sexual identity socially and/or professionally.

The support mechanisms provided by employers tends to focus predominantly on the needs of mainstream traditional expatriates which often exacerbates the discomfort LGBT expatriates (and their partners and/or children) face. McPhail et al. (2016) found that the 'comfort factor' tends to override legal status when determining 'LGBT-friendly' locations for expatriates. This means that, despite there being laws that criminalize gay sex such as in Singapore (e.g., Section 377A) and countries that do not recognize gay marriage (e.g., Singapore), if the host-country is generally welcoming of LGBT, as it is in Singapore (see Oswin, 2014; Vijayan, 2013; Zaccheus, 2015), then expatriates are less likely to object to relocating there as a potential place of employment. Conversely, even when a country does not expressly ban homosexuality, for example, Egypt (The Straits Times, 2015a) or has decriminalized same-sex relationships between consenting adults, as in India (see Joshi, 2013), informal discrimination can act as a deterrent to expatriation. In some countries being gay is also overshadowed by foreigner-status and hence in this context may be perceived as a safer destination.

Amongst support which organizations might provide for their LGBT expatriates, we suggest employee resource groups (ERGs) to facilitate 'coming out' to one's employer, legal advice and assistance for spousal employment, home-country 'Allies', and access to Allies and ERGs in the host country.

\section{Expatriate single parents}

Research on expatriate single parent families, including how best to manage, support and attract this segment of the workforce to engage in international mobility, is scant despite that Worldwide ERC (2008) estimates $9 \%$ of transferees undertaking a US domestic relocation are single parents. This suggests that single parents may be open to international relocation. An expatriate single parent is defined as a person who does not live with a spouse or partner and who is the primary caregiver for one or more children. The definition excludes single parents with adult offspring living independently in another location or the home-country, those engaged in official 'split family assignments' where parents/partners remain married/partnered, and families where the other parent is present in a cohabiting arrangement (McNulty, 2015a). Although expatriate single parent numbers appear to be low in comparison to two-parent families, increases are being reported. The Australian and New Zealand Association (ANZA) in Singapore, for instance, recently launched a single-parent networking forum (with more than 100 members) to provide support, advice, and friendship for adults and their families on topics such as legal rights, financial planning, immigration visas and emotional wellness (ANZA, 2014; Johnson, 2014). McNulty's (2015b) study on expatriate divorce provides further evidence that expatriate families are increasingly breaking down, with many single parents remaining abroad with their children during, and even after, divorce.

Expatriate single parents are faced with many unique challenges when deciding whether to live and work abroad. The first is finding new support networks in the host-country that can 
replicate the types of family support and networks some may have relied on back home, e.g., unpaid childcare support from parents, grand-parents, and other family members and close friends (Geist \& McManus, 2012). For many expatriates, this support must now be paid for in the form of domestic helpers, nannies, au pairs, and babysitters - or if they are fortunate enough, from a core group of personal friends. This is particularly difficult for those required to undertake business travel and then must leave their children in the care of 'strangers'. A second challenge is that an international relocation may also mean moving away from a significant other parent thus requiring careful management of international custody arrangements. Further, with the exception of those who are widowed or for whom the other parent has never had any involvement in the child/children's lives, the decision to relocate is not only dependent on the needs of the other (non-relocating) parent, but must also consider a child's well-being in terms of the quality of the relationship and contact he or she has (and can maintain) with their other parent (Elrod, 2010; Parkinson, Cashmore, \& Single, 2010).

These challenges require understanding and support from an employer which might include child care and domestic help when the expatriate needs to undertake work-related travel, facilitation of the child/ren accompanying the parent on short-term work trips, and legal advice in negotiating custody arrangements when an expatriate becomes a single parent during an assignment.

\section{Expatriate families with special needs and/or gifted children}

Relocating internationally with children has been shown to be challenging (Johnson, 2008; Kearney, 2002; Simens, 2011; Weeks, Weeks, \& Willis-Muller, 2010) which can be exacerbated when a family is relocating abroad with a special needs or gifted child/ren, particularly of school age (Mumma, 2001). A special needs child is defined as having intellectual and/or (multiple) disabilities of a physical or developmental nature, including autism, attention deficit hyperactivity disorder (ADHD), down syndrome, and cerebral palsy, among others. It also includes a child with learning disabilities, such as dyslexia or apraxia of speech. Tellingly, approximately $15 \%$ of children in the USA are diagnosed with disorders at any one time (Carlton \& Perelstein, 2013); thus the number of special needs children likely to be involved in an international relocation is increasing. A gifted child is defined as having exceptional and highly developed skills, interests and capabilities in sport, music, academics and art. When tested, they exhibit 'superior scores on measures of expected achievement, i.e., cognitive or intellectual ability assessments' (Reis \& McCoach, 2000: p. 157).

Supporting special needs or gifted children can be a significant undertaking for expatriate families (Cartus, 2012b). One of the biggest challenges for parents, especially in the pre-move stage when the decision whether to expatriate is still being made, is access to information about local or international schools that cater for the particular needs of their children. In the case of a special needs child, it is important to provide them with a combination of education and therapy (Clegg, 2013a; Tan, 2011). Only recently have specific schools been established in, for example, Asia, to meet this demand (e.g., Shine Academy in Shanghai and Melbourne Specialist International School in Singapore). For gifted children, the biggest challenge is how to avoid disadvantaging a child whose giftedness requires careful nurturing and specialized support. Emerging markets can be particularly challenging because special needs and gifted schools are often scarce and poor standards in education approaches prevail. Thus, special needs or gifted education support for expatriate families can be expensive: in addition to the psychological and emotional burden, many families can be required to pay hefty fees for dedicated educational support that may have been free in their home-country. 
On balance, the situation for special needs children is often worse than for those who are gifted. Carlton and Perelstein (2013) have found, for example, that while some international schools advocate services for special needs children, these are often mandated by law (e.g., 'inclusiveness') resulting in false advertising and actual services falling far short of parents' expectations. Furthermore, many international schools are for-profit and reluctant to spend additional money on services for a relatively small, but labour-intensive student cohort. Moreover, in oversubscribed locations such as Hong Kong and Brazil (Cartus, 2012a), international schools do not need to offer special education services to fill their enrolment numbers. Thus, on the one hand these reasons amount to few (international) schooling options for special needs children in expatriate families. On the other, some of the top selective international schools (e.g., Dulwich College, United World College of South East Asia, Tanglin Trust School) actively encourage the enrolment of gifted students on the basis that their programs and facilities are already geared towards achieving above average results in art, music, academics and sports for which a gifted student would be ideally suited.

A further difficulty for expatriate families that do decide to relocate with a special needs child is that the culture, values and even the vocabulary of special education in a particular country can differ significantly from what they are used to in their home country, thus adding to the stress a family may already be experiencing in a new location. Carlton and Perelstein (2013) contend that years spent understanding an education system in a parents' home country can be relegated as useless in a new location, leading to frustration, anger and exhaustion, and ultimately, adjustment problems for the entire family that could derail the assignment. Culturally, families may face discrimination, stigma and segregation among a child's peers in countries in which disabilities are little understood or accepted and even among other expatriate families.

Parents have a role to play when deciding to relocate abroad with a special needs or gifted child. Some may be tempted to play down their child's disability (for example, dyslexia) or talent (e.g., an exceptionally high IQ or musical ability) and keep quiet during the admissions process. For a special needs child this may result in being counseled out of the school at the end of term or the school year on the basis of poor academic results. For a gifted child it may result in significant underachievement (Whitmore, 1980). Both scenarios often necessitate that one parent repatriates back to the home country with their child/ren to access education while the other completes the assignment, i.e., the family enters into a split assignment. Diagnosis of a child's disorder or giftedness during an assignment can be just as difficult, particularly when a family is already grappling with moving and adjustment issues. The danger of ignoring a child's disorder, for instance, can be high and put down to 'moving woes' rather than being professionally assessed. These and other issues associated with special needs and gifted children have not been adequately addressed in extant literature and require further study. Of note is the likely number of potential candidates who turn down an international assignment and/or opt-out of international work opportunities because of a special needs or gifted child but whom, with appropriate organizational support, might not.

Companies lag behind in supporting special needs and gifted education for expatriate families, with few if any policies in place (Carlton \& Perelstein, 2013; Cartus, 2012b). Managing the emotional, psychological and financial expectations of a family is crucial; providing information about in- and out-of-school resources (e.g., Autism Association for Overseas Families at http://aaof.eseng.nl; US State Department list of overseas schools offering special education and/or gifted and talented programs at http://www.state.gov/documents/organization/176076.pdf) can be important to allow employees to make an informed decision about whether or not to engage in the move. Organizations might also provide assistance in identifying suitable schooling and out-ofschool-hours support. Organizations that are able to think outside the box and that are willing 
to incur a small additional expense are especially likely to succeed with special needs and/or gifted families; for example, while some locations may not cater for special needs children (e.g., Beijing), an employee who is based in Hong Kong who then commutes to Beijing for work can realize an international work opportunity while also meeting the needs of their child (Clegg, 2013a). Additionally, allowing a family a longer 'look-see' visit to explore local services for their child is likely to prevent problems later on. Scenario planning from the outset for a 'Plan B' location in the event of a failure in the first choice location (because Plan A cannot support a child's needs) can also help to facilitate an assignment. Thus, helping families to establish what local services will cost, what medical insurance will cover, and what the employer will contribute and do to assist can be critical success factors.

\section{Families with children adopted while living abroad (expatriate adoption)}

ORC (2008) and KPMG (2011) report that expatriate adoptions are increasingly supported by companies as part of the policy provisions provided to assignees, where 'dependent children' for the purposes of assignment benefits includes,

"those who rely on the assignee for the majority of their financial support, and are usually considered family for the purpose of calculating the assignee's international assignmentrelated allowances. This may include unmarried children (natural or adopted) typically under the age of 19 who would normally reside with the employee in the home country or other dependent relatives as approved by the organization's international assignment policy" (KPMG, 2011, p. 88).

We distinguish between home-country and expatriate adoption on the basis of where the adoption process is finalized. Typically, an adoption that is finalized in the home-country prior to expatriation will not legally impact on an assignee's ability to relocate abroad with a dependent adopted child if the child has obtained citizenship of the home-country. Expatriate adoption is different wherein an adopted child may not be granted citizenship of his or her adopted parents' home-country. Thus, there can be long-term residency complications in expatriates' home country arising from the adoption of children while living abroad.

Although only one academic study has explored expatriate overseas adoption (McNulty, 2015a), there is ample practitioner evidence (e.g., Anderson, 2011; Saurine, 2013; Solimine, 2015) to suggest that it is not only common among expatriates, but growing (see, for example, Adopt Abroad, Inc. at http://adopt-abroad.com). Expatriate adoption is defined by the Australian Government (2014, p. 3) as,

"[A citizen] who lives abroad that adopts a child from the country in which he or she is resident. Expatriate adoption can also include third country adoption, where [a citizen] living abroad in country B, adopts a child from country C. In both instances, the adoption must comply with the domestic adoption laws of the child's overseas country of usual residence and must be finalized in that country".

Adoption of a child during an international assignment undoubtedly involves myriad legalities for expatriates, but it can also present challenges to organizations. Prior to an actual adoption, many expatriates engage in lengthy and expensive pre-adoption activities that often require years of invested time and energy and for which there is no guarantee of success. This may impact on expatriates' performance and adjustment in a number of ways. First, expatriates and their families may be distracted by events in their personal life over a long period of time that an employer may be powerless to control. Second, because an overseas 
adoption frequently requires stable residency in one geographical jurisdiction on the part of parents, expatriates may be unwilling to re-assign or repatriate away from the host-country while the adoption is in process (Solimine, 2015). This may lead to a staffing problem for organizations. Third, not all adoptions are recognized in an expatriate's home country, even if an adoption visa is granted to a child. In Australia, for example, this necessitates that the child becomes a guardian of the State, with guardianship powers delegated to State and Territory adoption authorities; such an arrangement may be in place until either the provisions of the Act cease to apply, the child becomes an Australian citizen, or the child turns 18 (Australian Government, 2014). Again, obstacles such as this may present global staffing problems for organizations when an assignee is reluctant to repatriate or re-assign if their home- or new host-country does not legally recognize an internationally adopted child as a legal dependent. Thus, for people that start the adoption process prior to relocation, organizations might factor into their assignment planning the length of time the expatriate is likely to need to stay in the country and specific legal and immigration support needed upon repatriation.

\section{Multigenerational expatriate families}

While focusing on domestic employees rather than expatriates, Eikhof, Warhust \& Haunschild (2007) highlighted that organizations have tended not to consider the range of caring responsibilities of their employees and critique the ongoing focus on 30-something women with children while neglecting workers who care for sick and ageing parents or close relatives. We contend that this limited focus also applies to the world of expatriates. International assignments that involve multigenerational expatriate families represent a relatively new type of expatriation for organizations, albeit one that is growing particularly in regions such as Asia and South America (Brookfield Global Relocation Services, 2012). A multi-generational household is defined as one that includes at least two adult generations over the age of 25 (e.g., parents and grandparents, where either generation can be the household head) or two non-sequential generations, e.g., grandparents and grandchildren of any age (Parker, Passel, Taylor, \& Patten, 2014). In the case of expatriates, we define these families as constituting two or even three or more generations of family members living under the same roof and in the same host-country location during an international assignment. The most common type of multigenerational expatriate family is one with elderly family members (grandparents) who relocate abroad as dependents along with their adult children (whose company sponsors the move) and their grandchildren (Mumma, 2001). Brookfield Global Relocation Services (2014) and KPMG (2011) report that only 15\% of companies have policy provisions to assist in care for elderly family members, but of those that do, bringing extended family members on assignment (64\%) and supporting visits to the elderly family members in the home country (i.e. providing additional home leave; 55\%) are the most popular solutions. The most prevalent reason given for elderly care is that parent(s) suffer from chronic conditions and disabilities for which an expatriate needs to be their primary caregiver and/or take responsibility.

Illness and disabilities aside, multigenerational expatriate families can be especially prevalent in certain cultures and among certain family types, and are not uncommon during forced repatriation (see Conlin, 2012). In developing countries, obligations towards extended family members are diverse, and can be more onerous for single versus married individuals (Sidani \& Al Hakim, 2012) particularly females who are expected to care for elderly parents and other family members (especially younger siblings). This may necessitate that a single male or female expatriate is required to expatriate with one or both parents in order to continue to care for them. In the case of female expatriates or single parents, work-family responsibilities may restrict international work opportunities if their work-family conflict 
cannot be addressed. In some cultures, grandparents already assume a key role in the upbringing of children to allow both parents (or a single parent) to continue to work and pursue a career (Rosenblum, 2013). Doing so often provides financial, practical and emotional benefits for both sets of adults. In China, India and the Philippines the caregiver support provided by grandparents frequently enables women to balance the demands of their career with child rearing (Lee, Lee, Yu, Sun, \& Liu, 2000). While extant literature is all but silent on the existence of multigenerational expatriate families, we contend that a rise in their numbers is likely. Currently, more than 50 million US citizens live in a multigenerational arrangement (Taylor et al., 2010), representing 4.3 million multigenerational households (Lofquist, 2012). Thus, as women in particular (whether married or unmarried) begin to utilize the support of their relatives for childcare as a means of enacting their international career aspirations, the number of working age employees supporting elderly (often ill) family members increases, and as organizational policy improves to support this segment of the talent pool, companies are likely to see a greater number of requests for multigenerational family support during expatriation.

Organizational support for expatriates with accompanying families of varying generations might take the form of (subject to availability in particular locations) in-home nursing for elderly parents, carers for family members with disabilities, respite care, arrangements for out-of-home activities, and coordination of support services.

\section{Blended expatriate families (step-children, step-parents)}

Blended expatriate families generally look and act the same as most traditional nuclear expatriate families, with the exception that one or both parents has children from a previous relationship (McNulty, 2015a). This may require that one or more children live apart from the family for short or extended periods of time to facilitate joint custody arrangements with the other parent who may or may not be living in the same host-location as the child. Blended families may also consist of other family members who relocate as dependents (e.g., cousins, sisters, brothers, nieces, and nephews), i.e., relatives who are not part of the nuclear family but for whom an assignee has responsibility.

Blended expatriate families arising from the divorce of one or both parents face similar issues to those of expatriate single parents including, where relevant, requiring the other custodial parents' permission to relocate with a child, and additional home leave and custodial visits to allow a child to regularly visit the other parent. An additional challenge is that stepchildren frequently do not acquire the same last name as a step-parent or even the same family name as their (expatriate) parent if this parent has assumed their (new) married name; leading to confusion and/or stigmatization in an expatriate community when both parents and a child all have a different family name. There is no indication as to the number of blended expatriate families, although anecdotal evidence suggests that these types of families are common particularly in Western cultures where there is a high rate of divorce and re-marriage.

While blended expatriate families can face similar issues to those of expatriate families with special needs children (i.e., the additional stress of an international relocation can exacerbate work-family conflict), blended families may also have an 'edge' on family adjustment because the family unit has more experience with changes and the need for flexibility in living arrangements, and potentially adapts to changing circumstances with greater ease. We suggest that organizations need to develop specific policies to address the needs of blended families and those with step-children if they have not been adopted by the employee being assigned. For instance, as there are likely to be visa and immigration challenges if child is not a legal dependent of the assignee but only of their spouse, organizations need to consider how they can better facilitate blended family relocations by 
offering additional immigration assistance. Also, to address some of the social issues we have identified, organizationally-sponsored Employee Assistance Programs (EAPs) can provide expatriates with access to counseling and coaching services to assist children with acculturation.

\section{Introducing the special issue papers}

In the Call for Papers, we specifically noted several areas in which researchers might focus their papers including: status-reversal marriages/partnerships with a female breadwinner and a male trailing spouse; single expatriates unaccompanied by a partner or children, including split families; empty nesters or retired expatriates over the age of 60; expatriate couples cohabitating outside of legal marriages, with or without accompanying children; blended expatriate families with step-children; expatriate families adopting foreign children in the host-country during an assignment; lesbian, gay, bisexual or transgender expatriate partnerships, with or without children; single parents; expatriates with special needs children; and expatriates with multigenerational responsibilities on assignment.

The Call for Papers was advertised through the journal as well as electronic mailing lists for several leading international conferences. Following the initial closing date for paper submissions, we had received insufficient papers of suitable quality and fit with the special issue theme in order to proceed and thus extended the submission date and re-advertised the Call for Papers. Following the second call and extended date, we received enough papers that we deemed to have fit and thus proceeded with the review process. While we did receive a considerable number of enquiries and actual paper submissions through both calls and a number of papers were of very high quality and addressed important issues in the broad IHRM field, a significant number of papers did not focus sufficiently on the theme of the special issue. Indeed, though the focus of our special issue was on non-traditional expatriates, many submissions focused on non-traditional assignments, i.e., rather than addressing the expatriate and their family situation, the papers examined assignment types that deviated from the traditional long-term international assignment. While this suggests that there is a keen interest amongst researchers in exploring the changing nature of global mobility, it also highlighted to us that, though our own research has noted there is a wide diversity of expatriates relocating internationally, there is a dearth of research exploring these peoples' experiences, challenges, adjustment, competencies, and extent of organizational or other support. This leads us to conclude that what constitutes a non-traditional expatriate has not only been insufficiently examined but is also relatively ill-defined in extant literature.

Following a rigorous multi-stage review process we selected three papers to include in this special issue. The three papers examine three of the non-traditional family types, namely: generations of family; women frequent traveler expatriates in dual career families; and lesbian, gay, bisexual and transgender expatriates.

In the first paper entitled "The age of "liquid modernity": Self-initiated expatriates in Crete, their multi-generational families and the community", Clark and Altman consider multi-generational issues in respect to caring responsibilities of self-initiated expatriates working in Crete in a range of endeavours and lifecycle stages. Their assessment of how, for these individuals, expatriation decisions (relocating, staying or leaving) can be affected by family considerations as much as or more than personal career choices, makes a valuable contribution to the non-traditional expatriate literature in extending research about how family impacts on expatriation decisions but which has generally been limited to studies of spouse/partner and children. Within the broader project to which the authors refer, many of the self-initiated expatriates are self-employed or undertaking freelance work or volunteer work across a diverse range of occupations - areas which are not readily considered within the 
general expatriation literature which has instead tended to focus on expatriates in the business world. In accord with the fluidity of expatriation which the authors reflect upon as a framework for understanding this group of individuals, the sample represents a wide diversity of expatriate family situations encompassing, among others, expatriates with caring responsibilities for elderly parents, expatriates caring for children with special needs, expatriates maintaining links with family in home/other host countries, and an expatriate empty nester with children in another country. All family types reveal the extent to which such responsibilities affect the expatriate's commitment to remain in the host country. The authors examine a number of differing expatriate family situations which we include in our definition of non-traditional expatriates. Indeed, both family situation/commitments and affinity with Crete serve as push/pull factors and mean that some of the people in the case studies moved back and forth between Crete and their home countries with career/work often taking second place to the needs of accompanying family members or family in the home country.

This article extends the expatriate literature which has tended only to highlight the role of spouse/family for expatriate adjustment/non-adjustment and has generally focused on trailing spouses and dual career couples. By examining a wider range of family situations and their impact on expatriates who have self-initiated for indefinite periods of time, and undertaking the study in a community rather than workplace setting, the article by Altman and Clark underscores the need for a much more nuanced understanding of family and local country context variables which influence decisions of individuals in respect to expatriation, repatriation and re-expatriation. Importantly, the study highlights the need to understand extended families and communities, yet it is also limited by being based on a small sample in one part of a Mediterranean country which included people with strong expatriate network ties as well as linkages with locals. Such connections and community support may not be as prevalent for other expatriates with varying forms of accompanying family or for whom their expatriation is affected by ties/commitments with family in other countries. Thus the article does not explore the full range of multi-generational expatriate families. The authors were nonetheless able to access a sample of SIEs working in the non-corporate world through an expatriate association noting the ability to accommodate family needs when people are selfemployed. We suggest that this sample highlights the need to hear voices of expatriates with accompanying multi-generational families in corporate, government, non-government and not-for-profit organisational settings. Further research may ascertain the extent to which such organisations facilitate and support non-traditional multi-generational family situations and whether those who do not have support within the local community may find it more difficult to adjust when they have extended family commitments.

The second article by Fischlmayr and Puchmüller entitled "Married, mom and manager - how can this be combined with an international career?" focuses on female international managers. While there is considerable literature on female expatriates generally it has tended to consider women who are trailing spouses or in dual career couples (with or without accompanying children). What makes the authors' article important within this broad literature is that it examines the experiences and challenges for an erstwhile little explored component of the expatriate community, namely, women who are in dual career couples but who undertake frequent international work travel. Importantly, this article considers how they manage to balance their work and family commitments and in particular highlights the nontraditional nature of their family arrangements in that whilst they are travelling for work their male partners and other family members take responsibility for care of children (albeit with the women having a more traditional role of overseeing the organization of the care). The authors' analysis focuses on interview-based research with women employed across industries, in personal partnerships of varying lengths, with between one and four children, 
and from four countries in Asia, Europe, North America, and South America. Findings suggest that while some women will take their children (and partners and sometimes other care-givers) on their international trips, the women need to rely on their social support networks to assist with children's care and activities while they are travelling alone for business. This requires that there needs to be a high level of organization undertaken in advance of such trips and very regular communication home while absent. Thus, the authors' suggest that even while women are physically absent from their children's lives when they travel, they remain in the role as major caretaker through regular contact and taking charge of organizing child-care. This finding is consistent with the view in some cultures that women are seen as the primary caregiver, even when working full-time and traveling abroad for work (see Hutchings et al., 2012; Fischlmayr, 2002). Moreover, the authors' suggest that it is the women's particular socio-culture (and consequent institutional arrangements) that impacts mostly on the availability of child-care support.

This article addresses a gap in extant literature by highlighting that while many organizations have accommodated international assignments in which the expatriate has an accompanying spouse/partner and children through providing financial support, household, or other assistance, little consideration has thus far been given to how those who are on shortterm assignments or whom engage in frequent travel/commuter work are able to manage the demands of daily child rearing or other carer responsibilities. This raises two important issues. First, while the authors note the responsibility that falls on women to make necessary carer arrangements, more research is needed to consider the role that organizations play in facilitating women's international travel. Moreover, there are likely to be greater challenges faced by women undertaking international frequent travel roles who are single parents, or who have partners that also work extended hours and/or are required to travel for work, or who have children with special needs, or have other family members for whom they have carer commitments (in addition to children). This suggests that there is a need for organizations to consider how they can best assist employees with unique family responsibilities who are also required to undertake frequent work travel. This may include reimbursement for the costs associated with short-term nannies and other household support required during their absence, which can be viewed as less costly overall than the costs associated with an international long-term relocation. Further research might also consider the multiple, competing responsibilities of employees in a range of other family situations, including blended and step-families, and the implications this has for employees' ability to relocate short-term and/or to do frequent international work travel or commuter assignments.

The third paper by Paisley and Tayar entitled "Lesbian, gay, bisexual and transgender (LGBT) expatriates: An intersectionality perspective" highlights the virtually invisible place which LGBT expatriates have had within the broader expatriation and global mobility literature. While a growing body of literature has examined challenges and opportunities for LGBT people in workplaces generally, Paisley and Tayar address the particular issue of LGBT identity during expatriation given that disclosing one's LGBT identity in some cultural contexts may prove problematic, hostile or even dangerous. Though LGBT people may be highly mobile as expatriates and represented in greater numbers than their levels of disclosure may suggest, there has been limited research on the extent to which the blurring of work and home, as well as the greater input of management into employees' lives which necessarily occurs for expatriates, has affected LGBT expatriates relative to their heterosexual counterparts. Using a social constructivist intersectionality perspective, the authors highlight that the identity of individuals is multi-dimensional including not just gender, sexual identity, expression and orientation but also ethnic, social, work and other identities, and that such identities may alter across cultural contexts particularly in respect to the extent to which those cultures are tight (and thus potentially hostile) or loose (and thus potentially inclusive). They 
further suggest that organizational context may override national cultural context - for instance when an MNE has a strong diversity management agenda - thus resulting in LGBT expatriates experiencing more convergent intersectionality.

This article provides a valuable contribution to extant literature in moving the discussion beyond considerations of gender of expatriates in terms of male/female or issues in selection, support and challenges for female expatriates relative to male expatriates, by focusing on sexual orientation. Though the authors provide recommendations for organizations and human resource professionals in respect to providing diversity-conscious environments for LGBT expatriates, more research is needed to specifically consider what support mechanisms are already in place (e.g., ERGs, Allies) and the role that this may play in affecting individuals' choices around undertaking, and remaining in, international work/careers in their myriad forms. Recent research (e.g., Cho, Hutchings \& Marchant, 2013; O'Sullivan, 2013) has suggested that the increasing use of social media globally and more short-term and self-initiated assignments generally for expatriates has resulted in employees taking more ownership of their 'cross-cultural-ability' rather than relying on their organizations to offer cultural competency training. Future research is needed to examine LGBT expatriates' shifting identities (as affected by both national cultural context and organizational context) in respect to determining the extent of support which they require from the LGBT expatriate community relative to the support provided by their employers. Moreover, though research since the 1990s has considered the impact of spouse/partner and/or children on expatriate adjustment, such research has focused on heterosexual people. We suggest that Paisley and Tayar's research signals a need to understand not only LGBT expatriates' identities but also their family situation, including the challenges it may present for international relocation and the need for organizations to give greater consideration to supporting a wider range of family types amongst their assignee population.

\section{Future research agenda}

Having provided a critical literature review of the limited non-traditional expatriate literature to date as well as an overview of the articles in this Special Issue, we conclude by identifying three key themes warranting further research which can be used as a guide to develop our understanding of non-traditional expatriates and aid both researchers and practitioners in the field. In discussing these themes we also mention theories that can provide valuable underpinnings for researchers to use in analyzing the experiences, challenges and opportunities for non-traditional expatriates.

\section{Construct definition}

The first theme concerns construct definition: Who is a non-traditional expatriate? Further, how is the concept defined, and how should it be defined? Thus far the field has not developed a theory of expatriates although recent research has paused to reflect on the broad meanings of the word 'expatriate' and to argue for greater construct clarity. The research by McNulty and Brewster (2015), which they position as building on the work of Suddaby (2010), refers to boundary conditions under which expatriate employment is determined. They suggest the meanings of 'expatriate' is context-driven and requires analysis to understand what is (and is not) an expatriate beyond the narrow constraints of the term which does not adequately capture the diversity of roles and people engaged in international work. Their argument underpins the need for clarity around defining non-traditional expatriates also. While we have provided an initial definition in this article (based on our own studies and analysis of the limited extant research in the field), research on non-traditional expatriates is 
undoubtedly in its infancy. More research is needed to determine, specifically, the characteristics of non-traditional expatriates. Importantly, is our list of eight types of nontraditional expatriates exhaustive? Are there other people whom have not been considered in our definition and discussion? If so, who are they, where can we find them, and how do researchers access them so that they can be studied and understood? For example, while we acknowledge that age issues could extend our typology to also include semi-retirees and empty nesters, more in-depth research is needed to examine how the various stages of the family life-cycle impacts on the decision to expatriate taking into account the age of children and extended family members (aging parents).

Future studies could be undertaken based on family adjustment and adaption response (FAAR) theory (Patterson, 2002). Haslberger and Brewster (2008) utilized FAAR theory to examine traditional expatriate families' adjustment. They highlight that FAAR considers the balance between demands on the family and their capabilities to cope with demands which is mediated and moderated by the meanings the family attaches to its current and general situation. Where demands are met adjustment takes place, but where capabilities are insufficient crisis and culture shock occur with recovery being dependent upon adaptive capabilities. Stress theory may also be an appropriate theoretical lens because, in an expatiate context, it considers both work and non-work stressors (see Haslberger \& Brewster, 2008). Similarly, non-traditional families could be examined through a temporal lens using family development theory, which examines not only the stages of the family lifecycle (concluding with the empty nest; Hill and Rodgers 1964) but which also considers 'family career' stages (Rodgers, 1973) in relation to the careers of family members outside the home influencing family dynamics (White, 1991).

To further extend the small literature base on the topic of non-traditional expatriates, future studies need to examine more homogeneous samples of non-traditional expatriates in order to fully understand their unique characteristics. This would require, for example, separate studies of split families, single parents, and lesbians, gays, bisexual and transgender expatriates. While recent studies with homogenized samples across many types of nontraditional expatriates (e.g., McNulty, 2014, 2015a) have helped to provide an initial understanding of the issues these families face, more detailed studies are needed. This is because: (1) while non-traditional expatriates share common characteristics and challenges, each nonetheless has a unique set of circumstances that warrants attention both from a practical (policy) point of view and also theoretically in terms of the personally relevant elements and behaviors that drive non-traditional expatriates' acculturation success; and, (2) a single interview of, for example, a lesbian expatriate may not be generalizable across an entire population of LGBT expatriates, thus providing a poor representation of the actual life experiences of the different types of non-traditional expatriates.

\section{Barriers to mobility for non-traditional expatriates}

A second theme is focused on the barriers to mobility for non-traditional expatriates. How represented are non-traditional expatriates among the global talent pool? Do some organizations consider people who are in non-traditional families as unsuitable or too difficult to manage or too costly for expatriation? Similarly, do some sections of the non-traditional working population perceive that international work is not suitable for them (if so, why?) or, even if they would consider it, believe that they would not receive sufficient organizational or peer support, and how much support should they expect anyway? Stigma theory could provide a suitable basis for examining these questions. Goffman's (1986: 2-3) research about stigma suggests that, 
"While the stranger is present before us, evidence can arise of his possessing an attribute that makes him different from others in the category of persons available for him to be, and of a less desirable kind -- in the extreme, a person who is quite thoroughly bad, or dangerous, or weak. He is thus reduced in our minds from a whole and usual person to a tainted, discounted one. Such an attribute is a stigma, especially when its discrediting effect is very extensive; sometimes it is also called a failing, a shortcoming, a handicap. It constitutes a special discrepancy between virtual and actual social identity. Note that there are other types of discrepancy between virtual and actual social identity, for example the kind that causes us to reclassify an individual from one socially anticipated category to a different but equally well-anticipated one, and the kind that causes us to alter our estimation of the individual upward. Note, too, that not all undesirable attributes are at issue, but only those which are incongruous with our stereotype of what a given type of individual should be. The term stigma, then, will be used to refer to an attribute that is deeply discrediting, but it should be seen that a language of relationships, not attributes, is really needed."

The basis of Goffman's theory about stigma holds true for non-traditional expatriates wherein what others think about their personal family situation and the extent to which non-traditional employees may internalize their lack of conformity to social norms may impact on the decision to undertake international career opportunities. The crux of stigma theory is undoubtedly the link between psychological and sociological components and how they interrelate to impact on international career decisions for employees considered outside the norm.

Undoubtedly, organizations need to give greater consideration to selecting and supporting non-traditional expatriates in order to maximize the available global talent pool. There is also a critical need for researching and theorizing non-traditional expatriates. This includes studies that examine the reasons for non-traditional expatriates accepting international assignments or opting out of international assignment opportunities altogether, and the extent to which the combination of, and extent of cultural distance between, homeand host-country culture becomes an important consideration when deploying non-traditional expatriates and their families. In terms of specific barriers to mobility, is the 'expatriate glass ceiling' or 'glass border' which has been highlighted in relation to female expatriates real and does it act as a deterrent to engage in international mobility for other non-traditional expatriates i.e., is there a glass border for LGBT people and single parents also? Especially needed are studies that enable greater triangulation of data by analyzing the policies used to support the non-traditional segment of the expatriate talent pool. A valuable lens for analysing barriers to mobility could be stereotype theory which has already been applied in examining female expatriates (Hutchings, Michailova \& Harrison, 2013). Stereotyping can occur at an organizational level in the selection and support of expatriates or by colleagues and others in the host context. Such a theory could provide a suitable basis for considering bias and discrimination resulting from organizational practice or cultural beliefs which may impact on groups such as female expatriates, LGBT employees, single parents, split families and families who have children with special needs.

Researchers might also consider perspectives related to equal employment opportunity, affirmative action and diversity management (for a discussion see Strachan, Burgess \& Sullivan 2004). While some of these approaches and resultant human resource management practices are in their infancy in the developing countries in which non-traditional expatriates might be located, examining them would build on earlier research about female expatriates which has considered whether foreign women suffer gender prejudice as expatriates (as do local women) or are afforded the same opportunities as expatriate males (Adler,1987). Intersectionality theory could also be applied to consider the extent to which race, gender and 
class may conflate in affecting opportunities which organizations may provide to individuals in respect to (a) selection for, and support in, international positions, (b) determining how colleagues and other stakeholders interact with them, and (c) the (potential) expatriates' own sense of identity.

\section{Success factors for non-traditional expatriates}

A third theme is focused on the success factors for non-traditional expatriates. Our own research shows that while there are many challenges non-traditional expatriates face over and above those experienced by traditional expatriates, it does not necessarily translate into failure. In other words, non-traditional expatriates appear to be resilient problem-solvers who succeed in their international work often in spite of the situations they are forced to deal with (see, for example, the gay expatriate kidnapping case in McPhail \& McNulty, 2015). Thus, we need to know what are the success factors for non-traditional expatriates, how are these success factors developed, and how can these success factors be translated into effective policy support? Again, these questions could be examined with reference to stress theory or by considering family stress through the lens of critical life events and coping theories (see Lazarus, 1966, 1993). Similarly, resilience theory may provide valuable insights into how non-traditional expatriates cope with being different and the levels of support they may or may not receive as a result of being different (Fletcher \& Sarkar, 2013). While resilience theory has traditionally focused on the individual, research has evolved to consider how the family can provide coping and support mechanisms to assist individuals (in this case, the employed expatriate and his or her family members) to be resilient. Other research has, for example, considered the family as a unit thus demonstrating 'relationship' resilience (for a discussion see DuPlessis VanBreda, 2001). We contend, based on prior research (e.g., McNulty, 2014, 2015a), that the success of non-traditional expatriates is undoubtedly due, in part, to the dynamics of the relationships among family members and the extent to which it helps the family/individual adjust in a new location, taking into account their unusual status amongst others in the expatriate community.

Moreover, while substantive research over forty years has examined cross-cultural acculturation and adjustment of expatriates (e.g., Caligiuri et al., 1999; Johnson et al., 2003; Mamman, 1995; Selmer \& Leung, 2003a; Weeks et al., 2010), there is also a need to consider whether non-traditional expatriates may have more or less challenges when adjusting. Consideration could be given to the support offered to assist them. For instance, organisational citizenship behaviour, which involves discretionary activities by employees which contribute positively to organizational effectiveness (see Organ, 1988), might be used as lens for examining whether host country employees contribute to supporting diversity within their organizations through providing additional cross-cultural support to nontraditional expatriates at work and in a non-work context, which may result in higher levels of adjustment for them and their families. Another factor to consider is the extent to which nontraditional expatriate status is tolerated or not tolerated in various cultures and whether sending an expatriate to a 'tolerant' versus 'not tolerant' country impacts on their ability to be successful in the host-location. Moreover what is the duty of care of the employer in less tolerant contexts?

A third success factor for non-traditional expatriates is to understand whether they favour a particular type of assignment, assignment duration, or assignment location over others, and if so, why? Family decision making theory suggests that within families individuals have differing roles and role behavior and that these roles are not permanent or mutually exclusive in that roles will vary between families, over time, and across individual decisions (see Lackman \& Lanasa, 1993). Thus, family decision making theory could be 
examined in respect to how roles may vary over time for non-traditional families before, during and post-expatriation and the implications these relationships have in relation to the choice to expatriate and to continue expatriation. Family decision making theory could also be used as a lens through which to make comparisons between traditional and non-traditional family arrangements. In respect to expatriation decisions and choices, the experiences of splitfamily expatriates is an urgent area of study of which scholars know little about, despite that it is a topic of increasing concern in practice given the rise in numbers of split family assignments over the past five years (Brookfield Global Relocation Services, 2014; Copeland, 2009b). Likewise, virtually nothing is known about expatriates with special needs or gifted children, of which there are likely to be a more substantial number than is currently reported, given that nearly two-thirds of expatriates relocate abroad with their children (Brookfield Global Relocation Services, 2014; Cartus, 2012b).

While we have suggested some areas in which organizations might develop policy or provide support to the specific non-traditional expatriates we have identified, more research is needed to determine where, exactly, policy improvements are required for non-traditional expatriates and to determine the precise issues that need to be addressed. This is likely to result in determining strong (but flexible) boundaries in terms of when managers should say 'no' to some issues while considering others. These boundaries should emerge ideally from analysis of a combination of talent management considerations, size and skill level of the available candidate pool, and assignee supply and demand cycles. Additionally, research with practitioners is needed to determine where the responsibility for organizations to support nontraditional expatriates begins and ends in relation to what companies could, or should, not do. This is in line with recent research suggesting that there are limits to what organizational support can accomplish (McNulty, 2012; Tung 1998). Rather, expatriates' personality, attitude and 'cultural intelligence' for working abroad are posited as key individual characteristics of success. In developing specific policies and practices, organizations need to consider that most types of non-traditional expatriates will need some training and support but some will need more than others.

In summary, the challenges we faced in finding sufficient papers with direct topic relevance and significance to publish in this Special Issue suggests that the field of IHRM is yet to fully embrace studies of expatriates in non-traditional family situations. This implies that researchers are still generally sampling and accessing a narrow group of expatriates in mostly traditional family arrangements that heretofore needs extending. This gap may reflect that researchers are studying cohorts who are similar to them, or are the most available to access, or that amongst the global expatriate population few people specifically identify as being part of a non-traditional family and hence the specificities of their situation does not appear in published studies. This suggests that as researchers we may need to challenge our own assumptions about whom we consider to be expatriates. We might also delve further into the samples in our studies and ask whether demographic factors have a bearing on expatriates' experiences and the support they receive from their organizations. It could be expected that a challenge researchers face is the uncomfortableness some people feel in revealing aspects of their identity to employers and hence they are not being captured in the research being undertaken in this field (as recently noted among a study of LGBT expatriates; see McPhail, McNulty \& Hutchings, 2016). Researchers also may not be asking questions about demographics which, if done, would highlight issues of relevance as we noted earlier. This may in part reflect limitations in the research design that may be imposed by the requirement to act in accordance with ethical procedures of research and which subsequently prevents asking questions which may identify the personal characteristics of participants. We suggest that an important aspect of researching non-traditional expatriates in future studies is the necessity for researchers to devote considerable time in building relationships with a targeted 
sample of employees, organizations, and members of expatriate communities (e.g., LGBT associations and expatriate single parent support groups) in order to establish trust and credibility amongst potential research participants. In designing expatriate studies, we need to continue to question our use of 'typical' samples of traditional expatriates and their families to instead recognize the importance of considering other family types that may be harder to find and access but whose insights are likely to provide valuable extensions to our current understanding of expatriates in general.

\section{References}

Adler, N. (1979). Women as adrogynous managers: A conceptualization of the potential for American women in international management. International Journal of Intercultural Relations, 3(4), 407-436.

Adler, N. (1987). Pacific basin managers: A gaijin, not a woman. Human Resource Management, 26(2), 169-191.

Adler, N. (2002). Global managers: No longer men alone. The International Journal of Human Resource Management, 13(5), 743-760.

Anderson, E. (2011). An Australian/Ethiopian adoption story. Retrieved from http://whileabroad.com/adoption on 27 March 2014.

Andresen, M., Bergdolt, F., Margenfeld, J., \& Dickmann, M. (2014). Addressing international mobility confusion: Developing definitions and differentiations for self-initiated and assigned expatriates as well as migrants. The International Journal of Human Resource Management, 25(16), 2295-2318.

ANZA. (2014). ANZA Single parents networking forum. Retrieved from http://www.anza.org.sg/event/id/438839/Single-Parents-Networking-Forum.htm on 17 April 2015.

Arrow, K. (1973). The theory of discrimination. Discrimination in Labor Markets, 3(10), 333.

Australian Government. (2014). Fact Sheet - Expatriate Adoption. Retrieved from https://www.immi.gov.au/media/fact-sheets/36expat-adoption.pdf on 26 October 2014.

Baert, S. (2014). Career lesbians: Getting hired for not having kids? Industrial Relations Journal, 45(6), 543-561.

Baldridge, D., Eddleston, K., \& Veiga, J. (2006). Saying 'no' to being uprooted: The impact of famiy and gender on wilingness to relocate. Journal of Occupational and Organizational Psychology, 79, 131-149.

Beechler, S., \& Woodward, I. (2009). The global "war for talent". Journal of International Management, 15(3), 273-285.

Boatman, J., Wellins, R., \& Neal, S. (2011). Women work: The business benefits of closing the gender gap. Pittsburgh, PA: Development Dimensions International, Inc (DDI).

Bohlen, C. (2012, 8-9 December). Pragmatism for Dutch on gay marriage. International Herald Tribune.

Brookfield Global Relocation Services. (2012). Successful international assignments into developing locations. Woodridge, IL: Brookfield GRS.

Brookfield Global Relocation Services. (2014). Global relocation trends survey report. Woodridge, IL: Brookfield GRS.

Brookfield Global Relocation Services. (2015). Global relocation trends survey report. Woodridge, IL: Brookfield GRS.

Brooks, A., \& Edwards, K. (2009). Allies in the workplace: Including LGBT in HRD. Advances in Developing Human Resources, 11(1), 136-149. 
Caligiuri, P., Joshi, A., \& Lazarova, M. (1999). Factors influencing the adjustment of women on global assignments. The International Journal of Human Resource Management, 10(2), 163-179.

Caligiuri, P., \& Tung, R. (1999). Comparing the success of male and female expatriates from a US-based multinational company. The International Journal of Human Resource Management, 10(5), 763-782.

Carlton, J., \& Perelstein, L. (2013). Mobility challenges and strategies: Children with special needs. Mobility, 34(6), 54-57.

Cartus. (2012a). International Schooling in Hong Kong: It's Not All Gloom. Hong Kong: Cartus.

Cartus. (2012b). Trends in Global Relocation Survey - Biggest Challenges. Geneva: Cartus.

Cho, T., Hutchings, K. \& Marchant, T. (2013). Key factors influencing Korean expatriates' and spouses' perceptions of expatriation and repatriation. The International Journal of Human Resource Management, 24(5), 1051-1075.

Clegg, A. (2013a, 2 December). Expat life sets challenge for families with special needs. Financial Times.

Clegg, A. (2013b, 6 February). The trials of long-distance life. Financial Times.

Cole, N. (2012). Expatriate accompanying partners: The males speak. Asia Pacific Journal of Human Resources, 50(3), 308-326.

Cole, N., \& McNulty, Y. (2011). Why do female expatriates 'fit-in' better than males? Cross Cultural Management: An International Journal, 18(2), 144-164.

Colgan, F., \& McKearney, A. (2012). Visibility and voice in organisations: Lesbian, gay, bisexual and transgendered employee networks. Equality, Diversity, and Inclusion: An International Journal, 31(4), 359-378.

Collings, D., Scullion, H., \& Morley, M. (2007). Changing patterns of global staffing in the multinational enterprise: Challenges to the conventional expatriate assignment and emerging alternatives. Journal of World Business, 42(2), 198-213.

Collins, D. (2009). 'We're there and queer': Homonormative mobility and lived experience among gay expatriates in Manila. Gender and Society, 23(4), 465-493.

Collins, J., \& Callahan, J. (2012). Risky business: gay identity disclosure in a masculinized industry. Human Resource Development International, 15(4), 455-470.

Conlin, J. (2012, 31 August). 'The Waltons' meets 'Modern Family'. The New York Times.

Copeland, A. (2009). Voices from home: The personal and family side of international shortterm assignments. Brookline, MA: The Interchange Institute.

Dickmann, M., Doherty, N., Mills, T., \& Brewster, C. (2008). Why do they go? Individual and corporate perspectives on the factors influencing the decision to accept an international assignment. The International Journal of Human Resource Management, 19(4), 731-751.

Drago, R., Black, D., \& Wooden, M. (2005). Female breadwinner families: Their existence, persistence and sources. Journal of Sociology, 41(4), 343-362.

DuPlessis VanBreda, A. (2001). Resilience theory: A literature review. No. MPI/R/104/12/1/4. Pretoria, South Africa: South African Military Health Service.

Duxbury, L., Lyons, S., \& Higgins, C. (2007). Dual-income families in the new millenium: Reconceptualizing family type. Advances in Developing Human Resources, 9(4), 472-486.

ECA International. (2012). Commuter Assignment Survey. London: ECA International.

Eikhof, D., Warhust, C., \& Haunschild, A. (2007). Introduction: What work? What life? What balance? Critical reflections on the work-life balance debate. Employee Relations, 29(4), 325-333.

Elrod, L. (2010). National and international momentum builds for more child focus in relocation disputes. Family Law Quarterly, 44(3), 341-371, 373-374. 
Everly, B., \& Schwartz, J. (2014). Predictors of the adoption of LGBT-friendly HR policies. Human Resource Management, 54(2), 367-384.

Findlay, A. (2006). Brain strain and other social challenges arising from the UK's policy on attracting global talent. In C. Kuptsch \& E. Pang (Eds.), Competing for Global Talent (pp. 65-86). Geneva, Switzerland: International Institute for Labor Studies.

Fischlmayr, I., \& Kollinger, I. (2010). Work-life balance - A neglected issue among Austrian female expatriates. The International Journal of Human Resource Management, 21(4), 455-487.

Fischlmayr, I. (2002). Female self-perception as a barrier to international careers? The International Journal of Human Resource Management, 13(5), 773-783.

Fletcher, D. \& Sarkar, M. (2013). Psychological resilience: A review and critique of definitions, concepts, and theory. European Psychologist, 18(1), 12-23.

Fullerton, M. (2013). Diversity and inclusion - LGBT inclusion means business. Strategic HR Review, 12(3), 121-125.

Gedro, J. (2010). The lavender ceiling atop the global closet: Human resource development and lesbian expatriates. Human Resource Development Review, 9(4), 385-404.

Gedro, J., Mizzi, R., Rocco, T., \& van Loo, J. (2013). Going global: Professional mobility and concerns for LGBT workers. Human Resource Development International, 16(3), 282-297.

Geist, C., \& McManus, P. (2012). Different Reasons, Different Results: Implications of Migration by Gender and Family Status. Demography, 49(1), 197-217.

GMAC, NFTC, \& SHRM Global Forum. (2004). Ten years of global relocation trends: 19932004. Oakbrook, IL: GMAC.

Goby, V., Ahmed, Z., Annavarjula, M., Ibrahim, D., \& Osman-Gani, A. (2002). Determinants of expatriate success: An empirical study of Singaporean expatriates in The Peoples Republic of China. Journal of Transnational Management Development, 7(4), 73-88.

Goffman, E. (1986). Stigma - Notes on the Management of Spoiled Identity. New York, NY: Simon \& Schuster/Touchstone Books.

Green, A., Hogarth, T., \& Shackelton, R. (1999). Longer distance commuting as a substitute for migration in Britain: A review of trends, issues and implications. International Journal of Population Geography, 5, 49-67.

Guthrie, J., Ash, R., \& Stevens, C. (2003). Are women "better" than men? Personality differences and expatriate selection. Journal of Managerial Psychology, 18(3), 229-243.

Hancock, A-M. (2016). Intersectionality: An Intellectual History. New York, NY: Oxford University Press.

Harvey, M., \& Wiese, D. (1998). The dual-career couple: Female expatriates and male trailing spouses. Thunderbird International Business Review, 40(4), 359-388.

Haslberger, A. (2010). Gender differences in expatriate adjustment. European Journal of International Management, 4(1/2), 163-183.

Haslberger, A. \& Brewster, C. (2008). The expatriate family: An international perspective, Journal of Managerial Psychology, 23(3), 324- 346.

Haslberger, A., \& Vaiman, V. (2013). Managing talent of self-initiated expatriates: A neglected source of the global talent flow. In V. Vaiman \& A. Haslberger (Eds.), Managing Talent of Self-initiated Expatriates (pp. 1-15). London: Palgrave Macmillan.

Hendershott, A. (1995). Moving for work: The sociology of relocating in the 1990s. Lanham, MD: University Press of America.

Hill, R., and Rodgers, R. H. (1964). The developmental approach. In H. T. Christensen (Ed.), Handbook of Marriage and The Family, Chicago: Rand McNally.

Hippler, T. (2009). Why do they go? Empirical evidence of employees' motives for seeking or accepting relocation. The International Journal of Human Resource Management, 20(6), 1381-1401. 
Hofhuisa, J., van der Zeeb, K., \& Otten, S. (2015). Dealing with differences: the impact of perceived diversity outcomes on selection and assessment of minority candidates. The International Journal of Human Resource Management (in-press).

Hutchings, K., French, E., \& Hatcher, T. (2008). Lament of the ignored expatriate: An examination of organisational and social network support for female expatriates in China. Equal Opportunities International, 27(4), 372-391.

Hutchings, K., Lirio, P., \& Metcalfe, B. (2012). Gender, globalisation and development: A reevaluation of the nature of women's global work. The International Journal of Human Resource Management, 23(9), 1763-1787.

Hutchings, K. \& Michailova, S. (2016). Towards a more inclusive view of female expatriates, In Y. McNulty and J. Selmer (Eds.), Research Handbook of Expatriates, London: Edward Elgar (forthcoming).

Hutchings, K., Michailova, S., \& Harrison, E. (2013). Neither ghettoed nor cosmopolitan: A study of western women's perceptions of gender and cultural stereotyping in the United Arab Emirates, Management International Review, 53(2), 291-318.

Janssens, M., Cappellen, T., \& Zanoni, P. (2006). Successful female expatriates as agents: Positioning oneself through gender, hierarchy, and culture. Journal of World Business, 41(2), 133-148.

Johnson, E., Kristof-Brown, A., Van Vianen, A., De Pater, I., \& Klein, M. (2003). Expatriate social ties: Personality antecedents and consequences for adjustment. International Journal of Selection and Assessment, 11, 277-288.

Johnson, L. (2008). Handle with care: The experiences of children living abroad. Mobility, 29(11), 185-188.

Johnson, M. (2014, July). Single parents networking forum. ANZA Magazine. Singapore: ANZA.

Joshi, S. (2013). LGBT awareness in the Indian workplace. SHRM Online Global HR. Retrieved from http://shrm.org/hrdisciplines/global/articles/pages/lgbt-indianworkplace.aspx on 11 December 2013.

Kaplan, D. (2014). Career anchors and paths: The case of gay, lesbian and bisexual workers. Human Resource Management Review, 24(2), 119-192.

Kearney, S. (2002, 15 December 2002). Changing places: Help for children who move schools. The Sunday Telegraph.

King, D. (1988). Multiple jeopardy, multiple consciousness: The context of black feminist ideology. Signs, 14(1), 42-72.

KPMG. (2011). Global assignment policies and practices survey. Geneva: KPMG.

Lackman, C. \& Lanasa, J.M. (1993). Family decision-making theory: An overview and assessment, Psychology and Marketing, 10(2), 81-93.

Lauring, J., \& Selmer, J. (2010). The supportive expatriate spouse: An ethnographic study of spouse involvement in expatriate careers. International Business Review, 1, 59-69.

Lazarus, R.S. (1966). Psychological Stress and the Coping Process. New York, NY: McGraw-Hill.

Lazarus, R.S. (1993). Coping theory and research: Past, present, and future. Psychosomatik Medicine, 55, 234-247.

Lee, R., Lee, J.-J., Yu, E., Sun, S.-G., \& Liu, W. (2000). Living arrangements and elderly care: The case of Hong Kong. In W. Liu \& H. Kendig (Eds.), Who Should Care for the Elderly? An East-West Value Divide (pp. 269-296). Singapore: Singapore University Press $\&$ World Scientific Publishing Co.

Leonard, A. (2004). Sexual minority rights in the workplace. Brandeis Law Journal, 43, 145164. 
Linehan, M. (2002). Senior female international managers: Empirical evidence from Western Europe. The International Journal of Human Resource Management, 13(5), 802-814.

Lofquist, D. (2012). Multigenerational Households: 2009-2011. Washington, DC: United States Census Bureau.

Lowe, K., Downes, M., \& Kroeck, K. (1999). The impact of gender and location on the willingness to accept overseas assignments. The International Journal of Human Resource Management, 10(2), 223-234.

Makela, K., \& Suutari, V. (2009). Global careers: A social capital paradox The International Journal of Human Resource Management, 20(5), 992-1008.

Malecki, J., Day, B., Franklin, N., \& D'Argenio, R. (2013). Global mobility and the changing definition of family. Mobility, 34(2), 48-52.

Mamman, A. (1995). Expatriate adjustment: Dealing with hosts' attitudes in a foreign assignment. Journal of Transnational Management Development, 1(3), 49-70.

McDevitt-Pugh, L. (2011). The mobility of corporate lesbians. Signs I, 36(4), 798-806.

McDonnell, A., Lamare, R., Gunnigle, P., \& Lavelle, J. (2010). Developing tomorrow's leaders: Evidence of global talent management in multinational enterprises. Journal of World Business, 45(2), 150-160.

McFadden, C. (2015). Lesiban, gay, bisexual and transgender careers and human resource development: A systematic literature review. Human Resource Development Review, 14(2), 125-162.

McKeen, C., \& Bu, N. (2005). Gender roles: An examination of the hopes and expectations of the next generation of managers in Canada and China. Sex Roles, 52, 533-546.

McNulty, Y. (2012). "Being dumped in to sink or swim": An empirical study of organizational support for the trailing spouse. Human Resource Development International, 15(4), 417-434.

McNulty, Y. (2014). Women as female breadwinners in non-traditional expatriate families: Status-reversal marriages, single parents, split families, and lesbian partnerships. In K. Hutchings \& S. Michailova (Eds.), Research Handbook on Women in International Management (pp. 332-336). Cheltenham, UK: Edward Elgar.

McNulty, Y. (2015a). Acculturating non-traditional expatriates: A case study of single parent, overseas adoption, split family, and lesbian assignees. International Journal of Intercultural Relations, 49, 278-293.

McNulty, Y. (2015b). Till stress do us part: The causes and consequences of expatriate divorce. Journal of Global Mobility, 3(2), 106-136.

McNulty, Y. \& Brewster, C. (2016). Stopping the madness! Overcoming the disinclination to define the 'meanings' of expatriate. Proceedings of the U.S. Academy of Management HR Division Second International Conference (HRIC), 20-22 February, Sydney, Australia.

McPhail, R., \& McNulty, Y. (2015). "Oh, the places you won't go as an LGBT expatriate!" A study of HR's duty of care to lesbian, gay, bisexual and transgender expatriates in dangerous locations. European Journal of International Management, 9(6), 737-765.

McPhail, R., McNulty, Y., \& Hutchings, K. (2016). Lesbian and gay expatriation: Opportunities, barriers, and challenges for global mobility. The International Journal of Human Resource Management, DOI: 10.1080/09585192.2014.941903.

Mercer. (2014a). Mercer HR Worldwide Survey of International Assignment Polices and Practices. Geneva: Mercer.

Mercer. (2014b). North America LGBT Global Mobility Pulse Survey. London: Mercer HR.

Merignac, O., \& Grillat, M.-L. (2012). La constitution et la structuration des réseaux sociaux: un facteur clé de succès de l'expatriation [Setting up and structuring social networks: a key success factor of expatriation]. Management International, 17(1), 117-131. 
Merignac, O., \& Roger, A. (2005). L'impact du conjoint et de la famille sur leeadaptation des cadres expatriés [The impact of spouse and family on expatriate adjustment]. Revue de Gestion des Ressources Humaines, 58, 2-13.

Merignac, O., \& Roger, A. (2006). Mobilité internationale: le cas de leexpatriation en célibataire géographique [International mobility: the case of unaccompanied expatriation]. Revue Sciences de Gestion, 52, 63-79.

Meyskens, M., von Glinow, M., Werther, W., \& Clarke, L. (2009). The paradox of international talent: Alternative forms of international assignments. The International Journal of Human Resource Management, 20(6), 1439-1450.

Mumma, J. (2001). Relocation issues in today's workforce. Employment Relations Today, $28(1), 55-65$.

Office for National Statistics (UK). (2012). Comparing data sources on families and households. Retrieved from http://www.ons.gov.uk/ons/rel/family-demography/familiesand-households/2011/index.html on 21 February 2013.

ORC Worldwide. (2008). Worldwide survey of international assignment policies and practices. New York: ORC Worldwide.

Organ, D.W. (1988). Organizational citizenship behaviour: The good soldier syndrome. Lexington: Lexington Books.

O'Sullivan, S. (2013). The empowering potential of social media for key stakeholders in the repatriation process. Journal of Global Mobility, 1(3), 264-286.

Oswin, N. (2014). Queer time in global city Singapore: Neoliberal futures and the 'freedom to love'. Sexualities, 17(4), 412-433.

Ozturk, M., \& Rumens, N. (2014). Gay male academics in UK business and management schools: Negotiating heteronormativities in everyday work life. British Journal of Management, 25(3), 503-517.

Paik, Y., \& Vance, C. (2002). Evidence of back-home selection bias against US female expatriates. Women in Management Review, 17(2), 68-79.

Parker, K., Passel, J., Taylor, P., \& Patten, E. (2014). In post-recession era, young adults drive continuing rise in multi-generational living. Washington, DC: Pew Research Centre.

Parkinson, P., Cashmore, J., \& Single, J. (2010). The need for reality testing in relocation cases. Family Law Quarterly, 44(1), 1-34.

Patterson, J.M. (2002). Integrating family resilience and family stress theory. Journal of Marriage and Family, 64(2), 349-360.

Priola, V., Lasio, D., De Simone, S., \& Serri, F. (2014). The sound of silence: Lesbian, gay, bisexual and transgender discrimination in 'inclusive organizations'. British Journal of Management, 25(3), 488-502.

Punnett, B., Crocker, O., \& Stevens, M. (1992). The challenge for women expatriates and spouses: Some empirical evidence. The International Journal of Human Resource Management, 3(3), 585-592.

Reis, S. \& McCoach, D. (2000). The underachievement of gifted students: What do we know and where do we go? Gifted Child Quarterly, 44(3), 152-170.

Richardson, J. (2006). Self-directed expatriation: Family matters. Personnel Review, 35(4), 469-486.

Rocco, T., Landorf, S., \& Delgado, A. (2009). Framing the issue/framing the question: Inquiry, inclusion, advocacy, or hostility? In T. Rocco, J. Gedro, \& M. Kormanik (Eds.), Sexual Minority Issues in HRD: Raising Awareness. Advances in Developing Human Resources, 11, 7-23.

Rodgers, R.H. (1973). Family Interaction and Transaction: The Development Approach. Englewood Cliffs, NJ: Prentice Hall. 
Rosenblum, C. (2013, 13 December). Together again: Multigenerational households on the upswing. The New York Times.

Rothausen, T. (1999). "Family" in organizational research: A review and comparison of definitions and measures. Journal of Organizational Behavior, 20(6), 817-836.

Saurine, A. (2013, 26 July). Quicker, easier for Australian couples to adopt children while living overseas. Sydney Morning Herald.

Selmer, J., \& Leung, A. (2002). Career management issues of female business expatriates. Career Development International, 7(6), 348-358.

Selmer, J., \& Leung, A. (2003a). Expatriate career intentions of women on foreign assignments and their adjustment. Journal of Managerial Psychology, 18(3), 244-258.

Selmer, J., \& Leung, A. (2003b). Personal characteristics of female versus male business expatriates. International Journal of Cross Cultural Management, 3(2), 195-212.

Selmer, J., \& Leung, A. (2003c). Provision and adequacy of corporate support to male expatriate spouses: An exploratory study. Personnel Review, 32(1), 9-21.

Selmer, J., \& Leung, A. (2007). Symptom and problem focused coping strategies of business women expatriates and their socio-cultural adjustment in Hong Kong. Women in Management Review, 22(7), 588-605.

Shortland, S. (2009). Gender diversity in expatriation: evaluating theoretical perspectives. Gender in Management: An International Journal, 2(5), 365-286.

Sidani, Y., \& Al Hakim, Z. (2012). Work-family conflicts and job attitudes of single women: A developing country perspective. The International Journal of Human Resource Management, 23(7), 1376-1393.

Silver, M. (2014, 15 January 2014). In many cultures, gay life is fraught with risk. Sydney Morning Herald.

Simens, J. (2011). Emotional Resilience and The Expat Child. Great Britain: Summertime Publishing.

Solimine, K. (2015, 1 September). Expat adoptions raise logistical, legal, cultural challenges. Wall Street Journal.

Stahl, G., Björkmann, I., Farndale, E., Morris, S., Paauwe, J., Stiles, P., \& Wright, P. (2012). Leveraging your talent: Six principles of effective global talent management. MIT Sloan Management Review, 53(2), 25-42.

Strachan, S., Burgess, J., \& Sullivan, A. (2004). Affirmative action or managing diversity: What is the future of equal opportunity policies in organisations? Women in Management Review, 19(4), 196-204.

Suddaby, R. (2010). Construct clarity in theories of management and organization. Academy of Management Review, 35(3), 346-357.

Sullivan, S., Aldred, G., \& Taylor, J. (2013). The link between expatriate family issues and a shrinking - and changing - talent pool: What we know and where we need more research. Paper presented at the U.S. Academy of Management, Florida, USA, 9-13 August.

Süssmuth-Dyckerhoff, C., Wang, J., \& Chen, J. (2012). Women Matter: An Asia Perspective Harnessing female talent to raise corporate performance. PR China: McKinsey \& Co.

Tan, T. (2011, 7 November). Privately run special needs schools sprouting up. The Straits Times.

Taylor, P., Passel, J., Fry, R., Morin, R., Wang, W., Velasco, G., \& Dockterman, D. (2010). The return of the multi-generational family household. Washington, DC: Pew Research Centre.

Taylor, S., Napier, N., \& Mayrhofer, W. (2002). Women in global business: Introduction. The International Journal of Human Resource Management, 13(5), 739-742. 
Tharenou, P. (2008). Disruptive decisions to leave home: Gender and family differences in expatriation choices. Organizational Behavior and Human Decision Processes, 105, $183-$ 200.

Tharenou, P. (2010). Women's self-initiated expatriation as a career option and its ethical issues. Journal of Business Ethics, 95(1), 73-88.

The Straits Times. (2015a, 13 January). Egypt court acquits 26 of 'debauchery'. The Straits Times.

The Straits Times. (2015b, 21 May). Ireland's voters set to decide on same-sex marriage. The Straits Times.

Tung, R. (1998). American expatriates abroad: From neophytes to cosmopolitans. Journal of World Business, 33(2): 125-144.

Tung, R. (2004). Female expatriates: The model global manager? Organizational Dynamics, $33(3), 243-253$.

UNDP. (2014). Gert Ceville-Danielsen: Making equality work. Oslo Governance Centre. Retrieved from https://www.youtube.com/watch?v=BE5YMQEzfXA on 15 September 2015.

Ungar, M. (2000). State violence and lesbian, gay, bisexual and transgender (LGBT) rights. New Political Science, 22(1), 61-75.

Vijayan, K. (2013, 13 October). 'Better reasons needed' for gay sex law. The Sunday Times.

Weeks, K., Weeks, M., \& Willis-Muller, K. (2010). The adjustment of expatriate teenagers. Personnel Review, 39, 24-43.

Westwood, R., \& Leung, S. (1994). The female expatriate manager experience: Coping with gender and culture. International Studies of Management and Organization, 24(3), 64-85.

White, J.M. (1991). Dynamics of Family Development: A Theoretical Perspective. New York, NY: Guilford.

Whitmore, J. (1980). Giftedness, Conflict, and Underachievement. Boston, MA: Allen \& Bacon.

Wilson, A. (1996). How we find ourselves: Identity development and two spirit people. Harvard Educational Review, 66(2), 303-318.

Worldwide ERC. (2011). 2011 US Mobility Survey. Arlington, VA: Worldwide ERC.

Wroughton, L., \& Heavey, S. (2013, 2 August). US says visas from gay spouses will get equal treatment. Reuters.

Zaccheus, M. (2015, 22 March). Family travel policies for gay partners? Lesbians and child get travel claim approved, but insurers divided over how to deal with such cases. The Straits Times. 